\title{
KEWENANGAN NOTARIS DAN PPAT DALAM PROSES PEMBERIAN HAK GUNA BANGUNAN ATAS TANAH HAK MILIK
}

\author{
Oleh \\ I Gusti Agung Dhenita Sari \\ I Gusti Ngurah Wairocana \\ Made Gde Subha Karma Resen \\ Magister Kenotariatan Universitas Udayana \\ email : agungdhenita999@gmail.com
}

\begin{abstract}
ABSTRAK
Keberadaan Pasal 15 ayat (2) huruf f UUJNP mengenai kewenangan Notaris membuat akta yang berkaitan dengan pertanahan telah memunculkan berbagai macam penafsiran. Ketentuan Pasal 15 ayat (2) huruf f UUJNP memberikan kewenangan kepada Notaris untuk membuat Akta yang berkaitan dengan pertanahan namun tidak secara tegas mengatur mengenai batasan kewenangan Notaris terhadap kewenangan PPAT khususnya dalam proses pembuatan Akta terkait Pemberian Hak Guna Bangunan Atas Tanah Hak Milik. Kekaburan norma dalam menafsirkan makna pasal tersebut juga menimbulkan konflik kewenangan dalam pelaksanaannya. Oleh karena itu, masalah penelitian ini terkait dengan pembatasan Kewenangan Notaris terhadap Kewenangan PPAT dalam Proses Pemberian Hak Guna Bangunan Atas Tanah Hak Milik berdasarkan hukum yang berlaku dan makna ketentuan Pasal 15 ayat (2) huruf $\mathrm{f}$ UUJNP yang menyatakan kewenangan Notaris dalam membuat akta yang berkaitan denganpertanahan.

Penelitian ini merupakan penelitian hukum Normatif yang beranjak dari adanya kekaburan norma. Penelitian ini menggunakan 3 jenis pendekatan antara lain pendekatan perundang-undangan, pendekatan konsep dan pendekatan analitis. Teknik pengumpulan bahan hukum yang digunakan adalah kepustakaan dan system kartu. Analisis bahan hukum menggunakan teknik deskriptif dan argumentasi yang dikaitkan dengan teori dan konsep hukum yang relevan dengan permasalahan.

Hasil penelitian terhadap masalah yang dikaji yaitu Pembatasan kewenangan Notaris terhadap kewenangan PPAT dalam proses Pemberian Hak Guna Bangunan Atas Tanah Hak Milik yaitu Notaris hanya berwenang sebatas membuat Akta Perjanjian Pendahuluan Pemberian Hak Guna Bangunan Atas Tanah Hak Milik. Kemudian Makna pasal 15 ayat (2) huruf f adalah Notaris berwenang membuat akta yang berkaitan dengan pertanahan. Kewenangan Notaris dalam membuat akta pertanahan adalah selama dan sepanjang bukan merupakan akta pertanahan yang selama ini telah menjadi kewenangan PPAT, dengan kata lain Notaris tidak berwenang untuk membuat akta-akta pemindahan hak atas tanah, pemindahan hak milik atas rumah susun, dan pembebanan hak atas tanah.
\end{abstract}

Kata kunci: Kewenangan Notaris, Hak Guna Bangunan, Tanah Hak Milik

\section{ABSTRACT}

The existence of Article 15 of paragraph (2) letter $f$ UUJNP regarding the authority of Notary to make deed related to land has led to various kinds of interpretation. The provisions Article of 15 paragraph (2) paragraph letter $f$ UUJNP authorize the Notary to make deeds relating to land but not explicitly regulate the limits of the authority of Notary to the authority of PPAT especially in the process of making the Deed related to the Granting Building Rights the Property. The obscurity of the norm in interpreting the meaning of the article also creates a conflict of authority in its implementation. Therefore, the problem of this research is related to the limitation of Notary Authority over PPAT Authority in the Process of Land Use Right Use Right under the applicable law and the meaning of the provisions of Article 15 of paragraph (2) letter $f$ UUJNP stating the authority of Notary in making related deed with land. 
This thesis research is a normative legal research which departed from the vague of norm. This thesis research used 3 type of approach. There are statute approach, conseptual approach and analytical approach. The legal materil collection techniques used were the study of literature and card system. The analysis of the legal materials was conducted by using descriptive techniques and arguments associated with the theories and concepts of law which relevant to the issues.

The research findings of the problem under study, namely, that is studied is the Limitation of Notary's authority over the authority of PPAT in the process of Granting Building Rights the Property is Notary only authorized to extend the Deed of Introduction Agreement on the Granting Building Rights the Property. While the meaning of article 15 paragraph (2) letter $f$ is a Notary authorized to make deed related to land. Notary authority in making land deed is during and as long as it is not a land deed which has been the authority of PPAT, in other words the Notary is not authorized to make deeds of transfer of land rights, transfer of ownership rights over the apartment, and the imposition of land rights.

Keywords: Notary Authority, Building Rights, Freehold Land

I. PENDAHULUAN

\subsection{Latar Belakang Masalah}

Notaris sebagai pejabat yang berwenang membuat akta autentik dalam memberikan perlindungan hukum kepada masyarakat berpedoman kepada ketentuan yaitu Undang-Undang Republik Indonesia Nomor 2 Tahun 2014 Tentang Perubahan Atas UndangUndang Nomor 30 Tahun 2004 Tentang Jabatan Notaris (selanjutnya disebut UUJNP).

Lahirnya Pasal 15 ayat (2) huruf $f$ UUJNP mengenai kewenangan Notaris membuat akta yang berkaitan dengan pertanahan telah memunculkan berbagai macam penafsiran dan tanggapan pro maupun kontra, baik yang datang dari kalangan Notaris sendiri, maupun dari pihak lain yang merasa Undang-Undang tersebut telah memangkas kewenangan yang selama ini merupakan kewenangannya. UUJNP dibuat untuk menjamin kepastian, ketertiban, dan perlindungan hukum, yang berintikan kebenaran dan keadilan, namun Pasal 15 ayat (2) huruf $f$ UUJNP belum dapat menjamin akan hal itu karena terjadi kekaburan norma dalam menafsirkan makna pasal yang terkandung didalamnya dan mengakibatkan konflik kewenangan pelaksanaannya.

Notaris dan Pejabat Pembuat Akta Tanah (selanjutnya disebut PPAT) adalah pejabat yang berwenang dalam membuat Akta Otentik. Dalam hal pembuatan Akta terkait Pemberian Hak Guna Bangunan Atas Tanah Hak Milik, PPAT melahirkan produk hukum Akta Pemberian Hak Guna Bangunan Atas Tanah Hak Milik dan kewenangannya diatur secara tegas dalam Pasal 24 Peraturan Pemerintah Nomor 40 Tahun 1996 tentang Hak Guna Usaha, Hak Guna Bangunan Dan Hak Pakai Atas Tanah, sedangkan Notaris melahirkan produk Akta Perjanjian Pendahuluan Pemberian Hak Guna Bangunan Atas Tanah Hak Milik, namun kewenangannya dalam membuat akta ini, belum secara tegas diatur dalam UUJNP.

Pasal 15 ayat (2) huruf $f$ UUJNP yang menentukan bahwa Notaris berwenang pula membuat akta yang berkaitan dengan Pertanahan, menimbulkan penafsiran bahwa UUJNP tidak secara tegas mengatur mengenai batasan kewenangan dalam membuat akta dengan kata lain batasan mengenai akta-akta apa saja yang boleh dibuat oleh Notaris berkaitan dengan pertanahan karena dilihat dalam 
penjelasan pasal ini pun menyatakan "cukup jelas". Berdasarkan penafsiran ketentuan UUJNP tersebut, dapat dikatakan bahwa Pasal 15 ayat (2) huruf f UUJNP tidak secara tegas mengatur terkait kewenangan membuat akta yang berkaitan dengan pertanahan khususnya dalam pembuatan Akta Perjanjian Pendahuluan Pemberian Hak Guna Bangunan Atas Tanah Hak Milik.

Sehubungan dengan hal di atas, ketentuan Pasal 15 ayat 2 huruf $f$ menimbulkan kekaburan norma mengenai pemaknaan kewenangan "membuat akta yang berkaitan dengan pertanahan" karena ketentuan Pasal 15 ayat (2) huruf $f$ memberikan kewenangan kepada Notaris untuk membuat Akta yang berkaitan dengan pertanahan namun tidak secara tegas mengatur mengenai batasan kewenangan Notaris terhadap kewenangan PPAT khususnya dalam proses pembuatan Akta terkait Pemberian Hak Guna Bangunan Atas Tanah Hak Milik. Hal ini juga dapat dilihat dari pengaturan lebih lanjut dalam Penjelasan atas Pasal 15 ayat (2) huruf $f$ Undang-Undang Nomor 2 Tahun 2014 tentang Perubahan Atas Undang-Undang Nomor 30 Tahun 2004 Tentang Jabatan Notaris yang menyatakan bahwa penjelasan pasal ini cukup jelas. Kekaburan norma Pasal 15 ayat (2) huruf f UUJNP mengakibatkan konflik kewenangan dalam pelaksanannya dan juga mengakibatkan kerugian banyak pihak, tidak hanya Notaris dan PPAT, melainkan juga masyarakat banyak yang justru menginginkan adanya keadilan, kepastian serta perlindungan hukum.

Berdasarkan uraian latar belakang di atas penulis tertarik untuk membahas lebih lanjut mengenai permasalahanpermasalahan yang timbul terkait
Kewenangan Notaris dan PPAT Dalam Proses Pemberian Hak Guna Bangunan Atas Tanah Hak Milik.

\subsection{Rumusan Masalah}

Berdasarkan uraian tersebut di atas, maka permasalahan yang akan dibahas dalam penulisan tesis ini adalah :

1. Bagaimanakah pembatasan Kewenangan Notaris terhadap Kewenangan PPAT dalam Proses Pemberian Hak Guna Bangunan Atas Tanah Hak Milik berdasarkan hukum yang berlaku?

2. Bagaimanakah makna ketentuan Pasal 15 ayat (2) huruf $f$ UUJNP yang menyatakan kewenangan Notaris dalam membuat akta yang berkaitan dengan pertanahan?

\section{METODE PENELITIAN}

\subsection{Jenis Penelitian}

Penelitian ini merupakan penelitian hukum normatif. Penelitian hukum normatif yang dilakukan dalam penelitian ini yaitu dengan meneliti adanya kekaburan norma dalam pemaknaan ketentuan Pasal 15 ayat (2) huruf $f$ UUJNP yang menimbulkan konflik kewenangan dalam pelaksanaannya.

\subsection{Jenis Pendekatan}

Dalam penulisan karya ilmiah ini, menggunakan jenis pendekatan perundang-undangan (statute approach), pendekatan konsep (conseptual approach), dan pendekatan analitis (Analytical Approach).

\subsection{Sumber Bahan Hukum}

Dalam penelitian hukum normatif, sumber yang digunakan yaitu Bahan Hukum Primer, Bahan Hukum Sekunder, Bahan Hukum Tersier.

\subsection{Teknik Pengumpulan Bahan Hukum}

Dalam pengumpulan bahanbahan hukum dipergunakan teknik studi dokumen dan hasilnya dicatat dengan sistem kartu. 


\subsection{Teknik Analisis Bahan}

Hukum

Pada penelitian ini, analisis terhadap bahan-bahan hukum dilakukan dengan cara deskriptif analisis.

\section{TEORI DAN KONSEP}

\subsection{Teori Kewenangan}

Menurut konsep

kewenangan, berpendapat tindakan Philipus bahwa:

M.Hadjon setiap pemerintahan diisyaratkan harus bertumpu atas kewenangan yang sah. Kewenangan itu diperoleh melalui tiga sumber yaitu atribusi, delegasi dan mandat. Kewenangan atribusi lazimnya digariskan melalui pembagian kekuasaann negara oleh undang-undang, kewenangan delegasi adalah kewenangan yang berasal dari adanya pelimpahan kewenangan secara atributif sedangkan mandat tidak terjadi suatu pelimpahan kewenangan. ${ }^{1}$

Dalam kaitan dengan permasalahan penelitian, Teori Kewenangan ini digunakan untuk membahas dan menganalisis masalah tentang Pembatasan Kewenangan Notaris terhadap Kewenangan PPAT dalam Proses Pemberian Hak Guna Bangunan Atas Tanah Hak Milik. Dengan mengetahui wewenang tersebut memberikan kejelasan bahwa jabatan Notaris dan PPAT sama sama memiliki kewenangan untuk membuat akta yang berkaitan dengan pertanahan namun memiliki batasan pada masingmasing jabatan.

\subsection{Teori Penjenjangan Norma}

Menurut Teori Penjenjangan Norma (stuffenbau theorie) yang dikemukakan oleh Hans Kelsen seorang ahli filsafat hukum, dasar negara berkedudukan sebagai

${ }^{1}$ Philipus M.Hadjon, 1997, Penataan Hukum Administrasi, Tentang Wewenang, Fakultas Hukum Unair, Surabaya, hlm.2

norma dasar (grundnorm) dari suatu negara atau disebut norma fundamental (staatsfundamentalnorm).

Grundnorm merupakan norma hukum tertinggi dalam negara. Di bawah grundnorm terdapat normanorma hukum yang tingkatannya lebih rendah dari grundnorm tersebut. Norma-norma hukum yang bertingkat-tingkat tadi membentuk susunan hierarkis yang disebut sebagai tertib hukum.

Hans mengembangkan teori dari Hans Kelsen. Hans Nawiansky menghubungkan teori penjenjangan norma (stufenbau theory) hukum dalam kaitannya dengan negara. Menurut Hans Nawiansky, norma hukum dalam suatu negara juga berjenjang dan bertingkat membentuk suatu tertib hukum. Norma yang di bawah berdasar, bersumber dan berlaku pada norma yang lebih tinggi, norma yang lebih tinggi berdasar, bersumber dan berlaku pada norma yang lebih tinggi lagi demikian seterusnya sampai pada norma tertinggi dalam negara yang disebutnya sebagai Norma Fundamental Negara (staatsfundamentalnorm). Norma dalam negara itu selain berjenjang, bertingkat dan berlapis juga membentuk kelompok norma hukum yang terdiri atas 4 (empat) kelompok besar, Attamimi menunjukkan struktur hierarki tata hukum Indonesia dengan menggunakan teori Nawiasky. Berdasarkan teori tersebut, struktur tata hukum Indonesia struktur tata hukum Indonesia adalah: ${ }^{2}$

${ }^{2}$ Attamimi, Hamid A., 1990, Peranan Keputusan Presiden republik Indonesia dalam Penyelenggaraan Pemerintah Negara; Suatu studi Analisis Mengenai Keputusan Presiden yang Berfungsi Pengaturan dalam Kurun Waktu Pelita I Pelita IV. Disertasi Ilmu Hukum Fakultas 
1. Staatsfundamentalnorm:

Pancasila (Pembukaan 1945).

UUD

2. Staatgrundgesetz: Batang tubuh UUD 1945, Tap MPR, dan Konvensi Ketatanegaraan.

3. Formell gesetz: Undangundang.

4. Verordnung en Autonome Satzung: Secara hirarkis mulai dari Peraturan Pemerintah hingga Keputusan Bupati atau Walikota.

Hierarki peraturan perundangundangan di atas membawa konsekuensi, peraturan perundangundangan yang tingkatannya di bawah dibentuk, bersumber dan berdasar pada peraturan perundang-undangan yang ada di atasnya, demikian seterusnya hingga pada akhirnya sampai pada peraturan perundang-undangan yang paling tinggi tingkatannya.

Dengan demikian yang dimaksudkan dalam penulisan ini adalah pembentukan peraturan perundang-undangan yang ada di bawah senantiasa harus searah dan sejalan agar tidak menimbulkan konflik dengan peraturan perundang-undangan yang ada di atasnya.

\subsection{Teori Kepastian Hukum}

Menurut Gustav Radbruch, ada tiga tujuan dari hukum yaitu keadilan, kemanfaatan dan kepastian hukum. Teori kepastian hukum mengandung dua pengertian. Pertama, adanya aturan yang bersifat umum yang membuat individu mengetahui dan memahami perbuatan-perbuatan apa yang boleh dan tidak boleh dilakukan. Kedua, adanya keamanan hukum berupa jaminan kepastian hukum bagi individu dari kesewenangan pemerintah karena adanya aturan hukum yang bersifat umum sehingga individu

Pascasarjana Universitas Indonesia, Jakarta, hlm. 291 dapat mengetahui apa yang boleh dilakukan oleh Negara terhadap individu. ${ }^{3}$

Teori

Kepastian yang dimaksud dalam tesis ini adalah kepastian aturan hukum bukan kepastian tindakan yang sesuai dengan aturan hukum. Kepastian hukum secara normatif adalah ketika suatu peraturan dibuat dan diundangkan secara pasti karena dapat memberikan pengaturan secara jelas dan logis. Jelas dalam arti tidak menimbulkan keraguraguan atau multi tafsir dan logis dalam arti hukum tersebut tidak berbenturan atau menimbulkan konflik norma, kekaburan norma dan kekosongan norma. Teori Kepastian Hukum pada tesis ini menekankan pada kepastian mengenai makna ketentuan Pasal 15 ayat (2) huruf $f$ mengenai kewenangan Notaris dalam membuat akta yang berkaitan dengan pertanahan.

\subsection{Teori \\ Hukum \\ Perlindungan}

Menurut Philipus M. Hadjon, dibedakan dua macam perlindungan hukum, yaitu: ${ }^{4}$

1. Perlindungan hukum yang preventif yang bertujuan untuk mencegah terjadinya permasalahan atau sengketa, yang mengarahkan tindakan pemerintah untuk bersikap hati-hati dalam pengambilan keputusan berdasarkan kewenangan. Dalam hal ini Notaris sebagai pejabat umum harus hati-hati dalam menjalankan tugas jabatannya berdasarkan kewenangan yang diberikan Negara kepadanya untuk membuat suatu akta autentik guna menjamin kepastian hukum masyarakat.

2. Perlindungan hukum yang represif yang bertujuan untuk menyelesaikan permasalahan atau sengketa yang timbul, termasuk penanganannya di

${ }^{3}$ Peter Mahmud Marsuki, 2008, Pengantar Ilmu Hukum, Kencana Predana Media Group, Jakarta, hlm.158.

${ }^{4}$ Ibid, hlm.117. 
peradilan. Dalam hal ini dengan begitu banyaknya akta autentik yang dibuat oleh Notaris, tidak jarang Notaris dipermasalahkan oleh salah satu pihak atau pihak lainnya yang merasa dirugikan kepentingannya baik itu dengan pengingkaran aka nisi akta, tanda tangan maupun kehadiran pihak di hadapan Notaris.

Perlindungan hukum yang dimaksudkan dalam penulisan ini adalah perlindungan hukum preventif dan represif kepada masyarakat yaitu dengan melahirkan produk akta yang menjamin akan kepastian perbuatan hukumnya serta memberikan perlindungan hukum apabila terjadi sengketa dikemudian hari.

\subsection{Teori Interpretasi Hukum}

Menurut Von Savigny, interpretasi adalah merupakan suatu rekontruksi buah pikiran yang terungkapkan di dalam Undang-Undang. ${ }^{5}$ Mengintepretasi adalah tindakan untuk memberi tafsir terhadap norma yang sedang berlaku, apakah dalam penerapannya telah sesuai dengan arti, makna dan tujuan dirumuskannya norma tersebut. ${ }^{6}$ Pengertian penafsiran hukum dan/atau legal interpretasion, dapat dipahami ialah suatu usaha untuk menggali, menemukan dan memahami nilai-nilai dan normanorma yang hidup dan berkembang di dalam masyarakat, untuk dijadikan sebagai bahan (dasar) pertimbangan dalam menyusun hukum dan menetapkan suatu keputusan dalam menyelesaikan suatu permasalahan yang timbul dalam masyarakat, sehingga terwujud tujuan hukum itu sendiri,

${ }^{5}$ Peter Mahmud Marzuki, 2007, Penelitian Hukum, Cetakan ke-3, Kencana Predana Media Group, Jakarta, hlm. 106.

${ }^{6}$ I Made Pasek Diantha, 2016, Metedologi Penelitian Hukum Normatif Dalam Justifikasi Teori Hukum, Prenada Media Group, Jakarta, hlm. 84. yaitu "keadilan". 7 Penafsiran misalnya berupa: ${ }^{8}$

a. Penafsiran gramatikal, yaitu penafsiran dengan mencari arti katakatanya;

b. Penafsiran sistematikal, yaitu menafsirkan pasal Undang-Undang dengan menghubungkan dengan pasal-pasal lain dalam satu UndangUndang atau pasal-pasal dalam Undang-Undang yang lainnya;

c. Penafsiran historikal yang mencakup penafsiran dengan melihat sejarah terjadinya satu aturan perundangundangan misalnya pandanganpandangan yang mengemuka dalam tahap pembahasan rancangan di parlemen; dan penafsiran dengan melihat perkembangan suatu lembaga hukum yang diatur dalam peraturan perundang-undangan.

d. Penafsiran teleologis, yaitu mencari maksud dan tujuan dibuatnya peraturan perundang-undangan;

e. Penafsiran ekstensif dan restriktif. Penafsiran ekstensif adalah penafsiran yang memperlas arti kata dan penafsiran restriktif adalah mempersempit atau membatasi arti kata yang terdaat dalam peraturan perundang-undangan.

Menurut J.A.Pontier selain penafsiran-penafsiran tersebut di atas, ada juga penafsiran antisipatif, yaitu suatu penafsiran yang melihat jauh kedepan dari maksud norma tersebut dan penafsiran evolutif-dinamis, yaitu penafsiran yang disesuaikan dengan perkembangan pandangan social atau susila atau situasi kemasyarakatan. ${ }^{9}$ Menurut Peter Mahmud Marzuki, interpretasi dibedakan menjadi interpretasi berdasarkan kata-kata UndangUndang, interpretasi berdasarkan

${ }^{7}$ Zainuddin Ali, 2000, Ilmu Hukum dalam Masyarakat Indonesia, Yayasan Masyarakat Indonesia, Palu, hlm. 188

${ }^{8}$ I Made Pasek Diantha, op.cit., hlm. 154.

${ }^{9}$ B.Areif Sidharta, 2001, Rechtvinding, Cetakan 3, Laboratorium Hukum Universitas Katolik Parahyangan, Bandung, hlm. 24-33. 
kehendak pembentuk UndangUndang, interpretasi sistematis, interpretasi historis, interpretasi teleologis, interpretasi antipatoris, interpretasi modern. ${ }^{10}$

\subsection{Asas-Asas $\quad$ Preferensi Hukum}

Dalam teori hukum apabila terjadi kekaburan norma atau konflik norma maka pisau analisa yang digunakan adalah asas-asas hukum diantaranya sebagai berikut

\section{Lex Superior Derogat Legi Inferiori}

Asas yang menyatakan bahwa Undang-Undang yang lebih tinggi mempunyai derajat lebih tinggi sehingga terhadap peraturan yang lebih rendah dan mengatur objek yang sama harus disampingkan kecuali apabila substansi peraturan perundang-undangan lebih tinggi mengatur hal-hal yang oleh Undang-Undang ditetapkan menjadi wewenang peraturan perundang-undangan yang lebih rendah. ${ }^{11}$

\section{Lex Specialis Derogat Legi Generali}

Asas ini mengandung makna bahwa aturan hukum yang khusus menyampingkan aturan hukum yang umum. Ada beberapa yang harus diperhatikan dalam asas Lex Specialis Derogat Legi Generali ${ }^{12}$ :

a. Ketentuan-ketentuan yang didapati dalam aturan hukum umum tetap berlaku, kecuali yang diatur secara khusus

\section{${ }^{10}$ Ibid}

${ }^{11}$ Bagir Manan, Hukum Positif Indonesia, Yogyakarta, 2014, hlm. 58. Periksa juga penjelasan Pasal 7 ayat (5) Undang-Undang Nomor 10 Tahun 2004 tentang Pembentukan Peraturan Perundang-undangan sebagai berikut; "dalam ketentuan ini yang dimaksud dengan "hierarki" adalah penjenjangan setiap jenis peraturan perundang-undangan yang didasarkan pada asas bahwa peraturan perundang-undangan yang lebih rendah tidak boleh bertentangan dengan peraturan perundangan-undangan yang lebih tinggi”.

${ }^{12}$ Ibid., hlm. 58. dalam aturan hukum khusus tersebut.

b. Ketentuan-ketentuan lex specialis harus sederajat dengan ketentuan ketentuanketentuan lex generalis (Undang-Undang dengan Undang-Undang).

c. Ketentuan-ketentuan lex specialis harus berada dalam lingkungan hukum yang sama dengan lex generalis.

\section{Asas Lex Posterior Derogat Legi Priori}

Asas ini mengandung makna bahwa aturan hukum yang lebih baru menyampingkan aturan hukum yang lama dimana UndangUndang yang berlaku kemudian membatalkan Undang-Undang terdahulu sejauh mana mengatur objek yang sama. Asas Lex Posterior Derogat Legi Priori mewajibkan menggunakan hukum yang baru. Asas ini pun memuat prinsip-prinsip: ${ }^{13}$

a. Aturan hukum yang baru harus sederajat atau lebih tinggi dari aturan hukum yang lama;

b. Aturan hukum yang baru dan lama mengatur aspek/substansi yang sama. Asas ini bermaksud mencegah dualism peraturan yang berlaku yang dapat menimbulkan ketidakpastian hukum. ${ }^{14}$

Berdasarkan asas-asas hukum di atas, yang dimaksud oleh penulis adalah suatu peraturan tidak boleh terjadi suatu pertentangan atau benturan antara bagian-bagian tersebut dan juga tidak boleh terjadi duplikasi atau tumpang tindih (overlapping) antara satu peraturan dengan peraturan yang lainnya. Terkait permasalahan dalam penulisan, penulis menggunakan asas-asas hukum ini sebagai pisau analisa

${ }^{13}$ Ibid., hlm. 59.

${ }^{14}$ Ibid. 
terkait adanya tumpang tindih (overlapping) kewenangan antara Notaris dan PPAT dalam membuat akta yang berkaitan dengan pertanahan.

\subsection{Konsep Notaris}

Notaris merupakan suatu jabatan yang diciptakan oleh Negara berdasarkan UndangUndang. Seseorang yang memiliki gelar akademisi hukum, tidak dapat menjadi Notaris apabila tidak melalui pengangkatan yang dilakukan oleh Menteri. ${ }^{15}$ Notaris adalah pejabat umum yang berwenang untuk membuat akta otentik.

\subsection{Konsep Pejabat Pembuat Akta Tanah (PPAT)}

Berdasarkan Pasal 1 angka 1 Peraturan Pemerintah Republik Indonesia Nomor 24 Tahun 2016 Tentang Perubahan Atas Peraturan Pemerintah Nomor 37 Tahun 1998 Tentang Peraturan Jabatan Pejabat Pembuat Akta Tanah menentukan Pejabat Pembuat Akta Tanah, selanjutnya disebut PPAT, adalah pejabat umum yang diberi kewenangan untuk membuat aktaakta otentik mengenai perbuatan hukum tertentu mengenai hak atas tanah atau Hak Milik Atas Satuan Rumah Susun. PPAT adalah Pejabat umum sehingga jabatannya adalah jabatan publik (public office).

Berdasarkan Pasal 24

Peraturan Pemerintah Nomor 40 Tahun 1996 tentang HGU, HGB dan Hak Pakai Atas Tanah menjelaskan bahwa akta Pemberian Hak Guna Bangunan Atas Tanah Hak Milik dibuat oleh PPAT kemudian didaftar pada Kantor Pertanahan. Pasal ini mengandung makna bahwa PPAT memiliki kewenangan untuk membuat Akta Pemberian Hak

\footnotetext{
${ }^{15}$ Hartanti Sulihandari \& Nisya Rifiani, 2013, Prinsip-prinsip Dasar Profesi Notaris Berdasarkan Peraturan Perundang-undangan Terbaru, Dunia Cerdas, Jakarta, hlm.75.
}

Guna Bangunan Atas Tanah Hak Milik. Akta yang dibuat oleh PPAT merupakan akta otentik karena dibuat oleh dan dihadapan pejabat umum, menurut bentuk dan tata cara yang ditetapkan oleh PerUndang-Undangan. Akta PPAT merupakan salah satu bukti hak atas tanah untuk kelengkapan di Kantor Pertanahan. Oleh karena itu akta yang dibuat PPAT sangat penting artinya dalam proses pendaftaran hak ke Kantor Badan Pertanahan.

Dengan demikian berkaitan dengan pemberian Hak Guna Bangunan Atas Tanah Hak Milik, PPAT sebagai pejabat umum memiliki tugas yaitu melaksanakan sebagian kegiatan pendaftaran tanah dengan kewenangan membuat akta PPAT sebagai bukti telah dilakukannya perbuatan hukum pemberian hak guna bangunan atas tanah hak milik.

\subsection{Konsep Hak Guna Bangunan Atas Tanah Hak Milik}

Terkait pengaturan mengenai terjadinya Hak Guna Bangunan Atas Tanah Hak Milik diatur dalam Pasal 24 Peraturan Pemerintah Nomor 40 Tahun 1996 yang menentukan Hak Guna Bangunan atas Tanah Hak Milik terjadi dengan pemberian oleh pemegang Hak Milik dengan akta yang dibuat oleh Pejabat Pembuat Akta Tanah yang wajib didaftar pada Kantor Pertanahan serta saat itu juga telah mengikat pihak ketiga dan mengenai tata cara pemberian dan pendaftaran Hak Guna Bangunan;

IV. PEMBATASAN

KEWENANGAN NOTARIS TERHADAP

KEWENANGAN PPAT

DALAM

PROSES

PEMBERIAN HAK GUNA

BANGUNAN

ATAS 


\section{TANAH HAK MILIK BERDASARKAN HUKUM YANG BERLAKU}

4.1 Kewenangan Notaris di Bidang Pertanahan Menurut UndangUndang Jabatan Notaris Terkait Proses Pemberian Hak Guna Bangunan Atas Tanah Hak Milik

Notaris berdasarkan UndangUndang disebut sebagai pejabat umum yang diangkat oleh negara dan diberikan kewenangan khusus untuk membuat akta autentik. Kewenangan Notaris yang diberikan oleh Negara diatur dalam Pasal 15 UUJNP.

Kewenangan Notaris dalam membuat akta di bidang pertanahan bersumber dan undangundang, yaitu diatur dalam Pasal 15 ayat (2) huruf $f$ UUJNP yang dengan tegas dinyatakan bahwa Notaris berwenang membuat akta yang berkaitan dengan pertanahan. Dalam penjelasan pasal tersebut dikatakan "cukup jelas", padahal ketentuan tersebut sebenarnya memerlukan penjelasan berkaitan batasan akta-akta apa saja yang boleh dibuat oleh Notrais yang berkaitan dengan pertanahan mengingat dengan masih adanya pejabat lain yang oleh peraturan perundang-undangan juga diberi kewenangan untuk membuat akta di bidang pertanahan, yaitu Pejabat Pembuat Akta Tanah. Ketiadaan penjelasan tersebut menimbulkan problematika di lapangan, karena hingga saat ini PPAT masih menjalankan tugas dan wewenangnya membuat akta di bidang pertanahan.

Meskipun Notaris oleh Pasal 15 ayat (2) huruf $f$ UUJNP diberi kewenangan untuk membuat akta mengenai pertanahan, namun dalam prakteknya Notaris belum dapat menjalankan kewenangannya. Belum dapat menjalankan tersebut dalam arti meskipun sudah memiliki kewenangan namun produk aktanya tidak dapat dijadikan dasar untuk mendaftar ke Kantor Pertanahan Kabupaten/Kota seperti halnya akta PPAT yang juga diberi kewenangan membuat akta berkaitan dengan pertanahan.

Dalam perspektif teoritis, kewenangan Notaris dan PPAT dalam membuat akta yang berkaitan dengan pertanahan, khususnya kewenangan Notaris dalam proses Pemberian Hak Guna Bangunan Atas Tanah Hak Milik, Jika kita melihat hierarki peraturan perundang-undangan yang mengatur Notaris dengan PPAT, kedudukan PPAT diatur dalam suatu PP 24 Tahun 2016 Jo. PP No.37 Tahun 1998 sedangkan kedudukan Notaris diatur dalam UU No.2 Tahun 2014 Jo. UU No.30 Tahun 2004. Secara hierarki tingkatan kedudukan PPAT adalah di bawah kedudukan Notaris sehingga seharusnya peraturan perundang-undangan yang tingkatannya di bawah, dibentuk, bersumber dan berdasar pada peraturan perundang-undangan yang ada di atasnya. Dan sesuai dengan asas-asas preferensi hukum bahwa peraturan-peraturan yang ada, tidak boleh ada pertentangan/ber benturan dengan peraturan yang lainnya.

Apabila dikaitkan dengan kewenangan Notaris untuk membuat akta mengenai pertanahan, kewenangan Notaris merupakan kewenangan atributif, karena bersumber dan undangundang. Sehingga apabila dikaitkan kembali dengan hierarki peraturan perundang-undangan dan kewenangan Atribusi yang dimilikinya, kewenangan Notaris dalam proses pemberian Hak Guna Bangunan Atas Tanah Hak Milik dapat difasilitasi dengan Akta Notaris yaitu dalam bentuk Akta Perjanjian Pendahuluan Pemberian 
Hak Guna Bangunan Atas Tanah Hak Milik.

Pembuatan akta-akta yang berkaitan dengan tanah juga berada dalam lingkup hukum perdata, yakni untuk memberikan kepastian hukum dan sebagai bukti bagi suatu perbuatan hukum yang berkaitan dengan tanah, maka kriteria otentisitas akta-akta tanah tersebut tetap mengacu pada Pasal 1868 KUHPerdata. Sehubungan dengan hal tersebut maka pejabat umum yang berwenang untuk membuat akta otentik mengenai tanah adalah Notaris sebagaimana disebutkan dalam Pasal 1 angka 1 jo Pasal 15 ayat (2) huruf $\mathrm{f}$ UUJNP.

Dengan demikian karena telah memenuhi kualifikasi sebagai pejabat umum, maka akta-akta yang dibuat oleh Notaris termasuk pula akta yang berkaitan dengan 1868 KUHPerdata.

Menurut penulis, terkait kewenangan Notaris di Bidang Pertanahan menurut UndangUndang Jabatan Notaris dalam Proses Pemberian Hak Guna Bangunan Atas Tanah Hak Milik adalah walaupun Jenis-jenis akta autentik yang berkaitan dengan hubungan hukum para pihak, tidak dicantumkan secara khusus dalam UUJNP, namun apabila dianalisis dan dikaji tentang kewenangan atributif yang diberikan kepada UUJNP, Notaris memiliki kewenangan dalam hal membuat Akta Perjanjian di bidang pertanahan. Akta itu adalah Akta Perjanjian Pendahuluan Pemberian Hak Guna Bangunan Atas Tanah Hak Milik. Akta Perjanjian merupakan bukti tertulis yang memuat tentang hubungan hukum antara subjek yang satu dengan subjek hukum yang lainnya, di mana subjek hukum yang satu berhak atas suatu prestasi, sedangkan pihak lainnya berkewajiban untuk melaksanakan prestasinya. Sehingga dengan adanya akta itu, akan memberikan kepastian hukum bagi para pihak. Kepastian itu, meliputi kepastian sebagai alat bukti tentang para pihaknya, objeknya dan kepastian tentang hak dan kewajibannya. Akta Notaris dalam bentuk perjanjian merupakan perjanjian para pihak yang mengikat mereka yang membuatnya.

\subsection{Kewenangan Notaris di Bidang Pertanahan Menurut KUHPerdata Terkait Proses Pemberian Hak Guna Bangunan Atas Tanah Hak Milik}

Didalam Kitab UndangUndang Hukum Perdata perjanjian diatur dalam Buku Ketiga dari Pasal 1233 sampai dengan Pasal 1864 tentang perikatan. Pasalpasal tersebut tidak secara spesifik mengatur mengenai perjanjian akan tetapi mengenai perikatan.

Pengertian perjanjian sebagaimana terdapat dalam Pasal 1313 Kitab Undang-Undang Hukum Perdata menyatakan bahwa suatu perjanjian adalah suatu perbuatan dimana satu orang atau lebih mengikatkan dirinya terhadap satu orang atau lebih. Sedangkan yang dimaksud perikatan adalah suatu hubungan hukum antara dua pihak, dimana satu pihak ada hak dan di lain pihak ada kewajiban. ${ }^{16}$ Hubungan antara perjanjian dan perikatan sangat erat, sebab perjanjian menerbitkan atau menimbulkan adanya perikatan dan sekaligus merupakan sumber perikatan. Perjanjian merupakan suatu hal atau suatu peristiwa yang kongkrit, karena diwujudkan dalam bentuk yang tertulis, sedangkan perikatan lebih merupakan pengertian abstrak.

${ }^{16} \mathrm{~J}$. Satrio, 1998, Hukum Perikatan Yang Lahir Dari Perjanjian, Citra Aditya Bakti, Bandung, hlm. 5 
Perjanjian yang terdapat dalam Kitab Undang-Undang Hukum Perdata menganut sistem terbuka, yang mengandung arti bahwa hukum perjanjian memberikan kebebasan yang seluas-luasnya kepada masyarakat untuk mengadakan perjanjian yang berisi apa saja, asalkan tidak melanggar ketertiban umum, dan kesusilaan.

Sistem terbuka yang mengandung suatu asas kebebasan dalam membuat perjanjian dalam Kitab Undang-Undang Hukum Perdata lazimnya disimpulkan dalam Pasal 1338 ayat (1) yang berbunyi "semua perjanjian yang dibuat secara sah berlaku sebagai undang-undang bagi mereka yang membuatnya". Dari pengertian pasal tersebut, maka dapat dikatakan bahwa para pihak diperbolehkan untuk membuat perjanjian yang berisi dan berupa apa saja dan mengikat bagi mereka yang membuatnya sebagaimana undang-undang.

Salah satu perjanjian yang diatur dalam KUHPerdata yang berkaitan dengan pertanahan adalah Akta Perjanjian Pendahuluan Hak Guna Bangunan Atas Tanah Hak Milik. Akta Perjanjian Pendahuluan Pemberian Hak Guna Bangunan Atas Tanah Hak Milik adalah Perjanjian awal dimana pihak pertama sebagai pemberi Hak memberikan Hak Guna Bangunan Atas Tanah Hak Miliknya untuk dibangun oleh pihak kedua sebagai penerima Hak dan pihak kedua menerima pemberian Hak Guna Bangunan Atas Tanah Hak Milik-nya dengan objek, imbalan, ketentuan dan jangka waktu tertentu.

Akta Perjanjian Pendahuluan Pemberian Hak Guna Bangunan Atas Hak Milik masuk dalam jenis Partij Acte, bukan Ambtelijk acte artinya bahwa akta tersebut dibuat oleh para pihak dihadapan Notaris, oleh karena itu Notaris hanya menuangkan apa yang dijelaskan dan diakui oleh para pihak ke dalam akta yang dibuatnya, kebenaran atas apa yang disampaikan para pihak adalah tanggung jawab para pihak, bukan tanggung jawab Notaris, namun walaupun demikian Notaris harus melakukan penghati-hatian dalam pembuatan akta, termasuk dalam menerima keterangan-keterangan para pihak.

Berdasarkan hasil wawancara dengan salah satu Notaris/PPAT di Kabupaten Badung Dr.I GUSTI PUTU ANOM KERTI, SH.M.Kn., dalam diskusi yang dilakukan pada tanggal 07 April 2017, Beliau mengemukakan, Notaris harus melakukan penghati-hatian dalam pembuatan akta, termasuk dalam menerima keterangan-keterangan para pihak, Beliau menekankan mengenai fakta formil (data-data) dan fakta materiil (pengakuan/keterangan) yang disampaikan oleh para pihak tentang pembayaran imbalan oleh pihak Penerima hak kepada pihak pemberi hak. Menurut beliau, secara teknis Notaris/PPAT wajib meyakinkan apakah pembayaran imbalan sudah lunas atau tidak karena terkait dengan pelaksanaannya dalam praktek, Notaris/PPAT dihadapkan dengan kasus dimana ketika penerima hak telah melunasi pemberian imbalannya kepada pemberi hak namun syarat-syarat untuk pendaftaran ke BPN/Kantor Pertanahan belum terpenuhi seperti pajak BPHTB dan PPH belum dibayar, PPB masih tertunggak, Pengecekan Sertipikat dan Permohonan Zona belum terbit. Permasalahannya adalah tidak adanya kepastian serta perlindungan hukum saat adanya jeda waktu yang cukup lama yaitu antara ketika uang imbalan sudah lunas dengan belum terpenuhinya syarat pembuatan untuk 
pendaftaran akta PPAT ke Kantor Pertanahan Kabupaten/Kota. Karena pada saat uang imbalan sudah terbayar lunas maka secara de facto pemberian hak guna bangunan itu sudah beralih kepada penerima hak.

Terkait permasalahan di atas, menurut beliau disinilah peran Notaris dalam rangka menjamin kepastian serta memberikan perlindungan hukum bagi para pihak. Apabila uang imbalan sudah dilunasi maka Notaris harus membuatkan akta-akta yaitu Akta Perjanjian Pendahuluan Pemberian Hak Guna Bangunan Atas Tanah Hak Milik dan Kuasa. Akta Notaris tersebut lahir untuk memberikan kepastian dan perlindungan hukum bagi para pihak, serta sebagai jembatan untuk pembuatan Akta PPAT. Kepastian hukum bagi para pihak artinya apabila timbul sengketa atau permasalahan hukum dikemudian hari, akta ini dapat dijadikan sebagai alat bukti bahwa telah terjadi pemberian hak dengan imbalan dan jangka waktu tertentu dari pemberi hak kepada penerima hak sehingga para pihak mendapatkan perlindungan hukum atas perbuatan hukum yang telah dilakukannya. Sebagai jembatan untuk pembuatan Akta PPAT artinya bahwa akta perjanjian pendahuluan tersebut dapat dijadikan alat bukti yang merupakan perjanjian awal dari Akta PPAT yang nantinya akta PPAT tersebut digunakan dasar untuk didaftar pada Kantor Pertanahan Kabupaten/Kota setempat.

Mengenai hal di atas, penulis setuju dengan pandangan Notaris/PPAT Dr. I GUSTI PUTU ANOM KERTI, SH. M.Kn. bahwa Notaris berperan dalam memberikan kepastian hukum serta perlindungan hukum bagi para pihak yang melakukan perbuatan hukum Pemberian Hak Guna Bangunan Atas Tanah Hak Milik yaitu dengan melahirkan Akta Perjanjian Pendahuluan Pemberian Hak Guna Bangunan Atas Tanah Hak Milik.

Menurut penulis Akta

Perjanjian Pendahuluan Pemberian Hak Guna Bangunan Atas Tanah Hak Milik salah satunya bersumber dari ketentuan KUHPerdata karena telah memenuhi syarat-syarat sahnya perjanjian dan sesuai dengan asasasas dibuatnya suatu perjanjian, dengan kata lain walaupun akta ini tidak dicantumkan secara khusus dalam KUHPerdata namun hal ini merupakan suatu perikatan yang muncul dari perjanjian sebagaimana diatur dalam Pasal 1313,1320,1338 KUHPerdata. Kemudian akta tersebut merupakan akta otentik dengan jenis Partij Acte/Akta Pihak dan dibuat berdasarkan Undangundang sebagaimana dijelaskan dalam KUHPerdata.

\subsection{Kewenangan PPAT dalam Proses Pemberian Hak Guna Bangunan Atas Tanah Hak Milik}

Kewenangan PPAT yang dalam bahasa Inggris, disebut authority, sedangkan dalam bahasa Belanda, disebut dengan autoriteit atau gezag merupakan kekuasaan yang diberikan oleh hukum kepada PPAT untuk membuat akta. ${ }^{17}$

Berdasarkan Peraturan Pemerintah Republik Indonesia Nomor 24 Tahun 2016 Tentang Perubahan Atas Peraturan Pemerintah Nomor 37 Tahun 1998 Tentang Peraturan Jabatan Pejabat Pembuat Akta Tanah, PPAT bertugas pokok melaksanakan sebagian kegiatan pendaftaran tanah dengan membuat akta sebagai bukti telah dilakukannya

${ }^{17}$ Salim HS, 2016, Teknik Pembuatan Akta Pejabat Pembuat Akta Tanah (PPAT) Ed.1-Cet.1, PT.RajaGrafindo Persada, Jakarta, hlm.94 
perbuatan hukum tertentu mengenai hak atas tanah atau Hak Milik Atas Satuan Rumah Susun yang akan dijadikan dasar bagi pendaftaran perubahan data pendaftaran tanah yang diakibatkan oleh perbuatan hukum itu. Perbuatan hukum sebagaimana dimaksud adalah Pemberian hak guna bangunan/hak pakai atas tanah Hak Milik.

Berdasarkan Pasal 24

Peraturan Pemerintah Nomor 40 Tahun 1996 tentang HGU, HGB dan Hak Pakai Atas Tanah menjelaskan bahwa akta Pemberian Hak Guna Bangunan Atas Tanah Hak Milik dibuat oleh PPAT kemudian didaftar pada Kantor Pertanahan.

Menurut penulis, PPAT secara tegas memiliki kewenangan dalam hal pembuatan Akta Pemberian Hak Guna Bangunan Atas Tanah Hak Milik. PPAT melahirkan produk hukum Akta Pemberian Hak Guna Bangunan Atas Tanah Hak Milik yang diatur dalam Pasal 24 Peraturan Pemerintah Nomor 40 Tahun 1996 tentang Hak Guna Usaha, Hak Guna Bangunan Dan Hak Pakai Atas Tanah.

\subsection{Pembatasan Kewenangan Notaris Terhadap Kewenangan PPAT Dalam Proses Pemberian Hak Guna Bangunan Atas Tanah Hak Milik}

Menurut penulis terkait pembatasan kewenangan Notaris terhadap kewenangan PPAT dalam proses Pemberian Hak Guna Bangunan Atas Tanah Hak Milik yaitu Notaris hanya berwenang sebatas membuat Akta Perjanjian Pendahuluan Pemberian Hak Guna Bangunan Atas Tanah Hak Milik. Akta tersebut tidak dapat dijadikan dasar langsung untuk mendaftar ke Kantor Pertanahan Kota/Kabupaten. Lahirnya Akta Perjanjian Pendahuluan ini disebabkan oleh tidak adanya kepastian serta perlindungan hukum saat adanya jeda waktu yang cukup lama yaitu antara ketika uang imbalan sudah lunas dengan belum terpenuhinya syarat pembuatan Akta PPAT untuk pendaftaran ke Kantor Pertanahan Kabupaten/Kota. Maka dari itu Akta ini merupakan akta awal sebagai jembatan untuk selanjutnya dibuatkan akta PPAT yang nantinya dapat digunakan sebagai dasar untuk mendaftar ke Kantor Pertanahan Kota/Kabupaten setempat. Notaris sebagai pejabat harus melindungi para pihak dalam melakukan perbuatan hukum. Sehingga dengan lahirnya Akta tersebut, Notaris dapat memberikan kepastian berupa alat bukti yang sempurna serta memberikan perlindungan hukum kepada para pihak guna mencegah timbulnya sengketa terhadap perbuatan hukum yang dilakukannya.

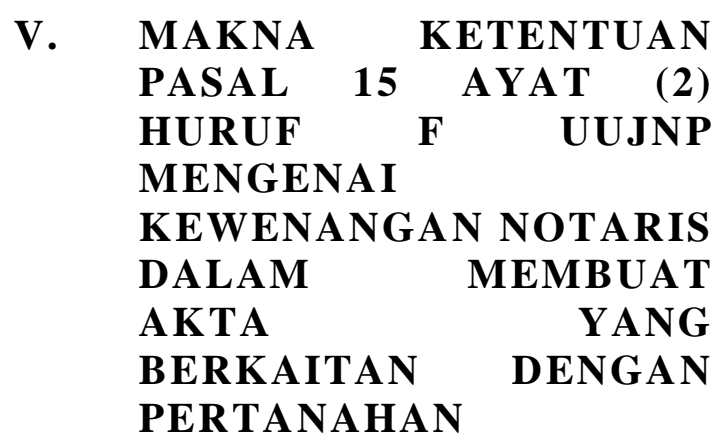

5.1 Makna Kewenangan Notaris Menurut Pasal 15 Ayat (2) Huruf f UUJNP

\subsubsection{Menurut Arti Kata}

Dalam ketentuan UUJNP, baik dalam penjelasan pasal demi pasal, maupun ketentuannya sendiri tidak dapat ditemukan secara jelas mengenai makna kalimat akta yang berkaitan dengan pertanahan. Dan sampai saat ini ketentuan mengenai kewenangan tersebut belum diatur dalam suatu peraturan pelaksana. Ketentuan Pasal 15 ayat (2) huruf f tidak memerintahkan untuk lebih 
merinci atau mengatur lebih lanjut melalui Peraturan Pemerintah.

Pasal 15 ayat (1) UUJNP menentukan bahwa Notaris berwenang membuat "semua perjanjian....: dapat ditafsirkan atau mengandung makna bahwa jenis perjanjiannya adalah perjanjian berkaitan dengan pertanahan.

Pasal 15 ayat (1) UUJN juga menentukan bahwa Notaris berwenang membuat akta otentik sepanjang pembuatan akta-akta tersebut tidak juga ditugaskan atau dikecualikan kepada pejabat lain atau orang lain. Berdasarkan ketentuan tersebut, maka pada dasarnya kewenangan Notaris untuk membuat akta otentik adalah terbatas. Salah satu yang membatasi adalah kewenangan pejabat lain. Bila ketentuan tersebut dihubungkan dengan aktaakta pemindahan hak atas tanah dan Hak Milik Atas Satuan Rumah Susun, dan pembebanan hak tanggungan, maka akta-akta tersebut sebagaimana diatur dalam beberapa ketentuan adalah merupakan kewenangan PPAT. Pengaturan mengenai kewenangan PPAT tersebut diatur baik dalam Undang-undang, Peraturan Pemerintah, maupun dalam ketentuan peraturan pelaksanaanya.

Berdasarkan

batasan

kewenangan yang termaktub dalam Pasal 15 ayat (2) UUJN, maka Notaris berwenang untuk membuat akta-akta yang berkaitan dengan pertanahan yaitu dalam bentuk semua perjanjian, sepanjang pembuatan akta-akta tersebut tidak juga ditugaskan atau dikecualikan kepada pejabat lain atau orang lain. Akta-akta tersebut seperti akta kelahiran dan akta kematian yang dibuat oleh Pejabat Kantor Catalan Sipil, risalah telang yang dibuat oleh Pejabat Lelang, dan akta-akta pemindahan hak atas tanah dan akta pembebanan hak atas tanah yang merupakan kewenangan dari PPAT.

\subsubsection{Menurut Lainnya. \\ Ketentuan}

Pemahaman Pasal 15 ayat (2) huruf $f$ UUJNP haruslah dihubungkan dengan Pasal 17 huruf g UUJN, yang dalam ilmu hukum dikenal dengan metode penafsiran sistimatis. Dalam ketentuan Pasal 17 huruf g UUJN menentukan Notaris dilarang merangkap Jabatan sebagai PPAT di luar wilayah Jabatan notaris.

Secara gramatikal Pasal ini mempunyai beberapa arti atau makna yaitu:
a) Notaris boleh merangkap sebagai PPAT asal saja Jabatan PPAT yang dirangkapnya masih termasuk dalam wilayah Jabatan Notaris;

b) Dengan adanya pengakuan jabatan rangkap ini, maka Notaris dan PPAT mempunyai kewenangan yang berbeda atau kewenangan Notaris menurut UUJN tidak sama dengan kewenangan PPAT, kecuali ditentukan lain oleh UU lain;
c) Adanya peraturan perundang- undangan lain yang mengatur kewenangan PPAT.

Berdasarkan penafsiran secara sistimatis, Pasal 17 huruf g UUJN memberikan arti bahwa yang dimaksud dengan Pasal 15 ayat (2) huruf $f$ UUJN adalah kewenangan notaris membuat akta-akta yang berkaitan dengan pertanahan dalam arti sempit, yaitu kewenangan untuk membuat aktaakta tanah yang tidak termasuk kewenangan PPAT berdasarkan PP 24 Tahun 2016 Jo. PP 37 tahun 1998.

\subsection{Pendapat Fraksi Saat Pengesahan UUJN.}

Pendapat Fraksi Partai Persatuan Pembangunan Dewan Perwakilan Rakyat Republik 
Indonesia, dalam alenia 12 menyebutkan:

Pekerjaan Notaris meliputi pembuatan beragam akta, tidak kurang dari 240 (dua ratus empat puluh) jenisnya, baik yang standar maupun yang memeriukan keahlian dalam merumuskan kehendak para pihak yang minta dituangkan dalam akta, Hanya saja dalam hal ini, mengapa Pemerintah masih membatasi pembuatan akta tanah tidak untuk semua Notaris, tetapi justru membenarkan dapat pula diangkat menjadi PPAT. Oleh karena itu Fraksi Partai Persatuan Pembangunan

Pemerintah agar segera pula meninjau kembali Peraturan Pemerintah yang mengatur PPAT dengan tidak mewajibkan Notaris masih memeriukan pengangkatan khusus dari instansi lain untuk jabatan PPAT. Kekuasaan kehakimam melalui peradilannya menghargai produk Notaris, baik sebagai akta otentik maupun grose akta yang mempunyai kekuatan eksikutorial seperti halnya putusan pengadilan yang telah memperoleh kekuatan hukum tetap. Tetapi mengapa instansi sesama pemerintah justru rnembedakannya. Dengan semakin banyaknnya PPAT yang kualitatif diharapkan pelayanan kepada masyarakat lebih ditingkatkan dan murah, egoisme sektoral dari setiap departemen tanpa mau berkoordinasi harus segera berakhir, tidak dipelihara melalui perundang-undangan. ${ }^{18}$

Peraturan Pemerintah Nomor 37 Tahun 1998 dengan Pasal 15 ayat (2) huruf $f$ UUJN tidak terjadi pertentangan norma. Peraturan Pemerintah Nomor 37 Tahun 1998 adalah merupakan pelaksanaan dari Pasal 19 UUPA,

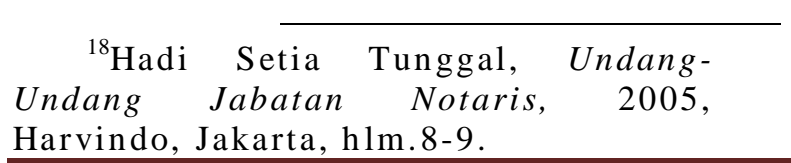

oleh karenanya, kewenangan Notaris untuk membuat akta yang berkaitan dengan pertanahan sebagaimana diatur dalam Pasal 15 ayat (2) huruf f UUJN, tidak dapat membatalkan ketentuan-ketentuan dalam Peraturan Pemerintah Nomor 37 Tahun 1998.

\subsection{Menurut Para Ahli Hukum} Menurut Dr. Habib Adjie, S.H., M.Hum., Kewenangan Notaris membuat akta yang berkaitan dengan pertanahan yaitu Pasal 15 ayat (2) huruf f UUJN memberikan kewenangan Notaris untuk membuat akta yang berkaitan dengan pertanahan. Ada 3 (tiga) penafsiran pasal tersebut, yaitu ;

1. Notaris telah mengambil alih semua wewenang PPAT menjadi wewenang Notaris atau telah menambah wewenang Notaris.

2. Bidang pertanahan menjadi wewenang Notaris

3. Tetap tidak ada pengambilalihan darin PPAT atau pengambilalihan wewenang kepada Notaris, baik PPAT maupun Notaris telah mempunyai wewenang sendiri-sendiri.

Hahib Adjie mengatakan bahwa kewenangan notaris untuk membuat akta-akta mengenai pertanahan sebagaimana disebutkan dalam Pasal 15 ayat (2) huruf $f$ adalah merupakan kewenangan khusus karena mengenai perbuatan hukum tertentu. Kewenangan Notaris dalam membuat akta pertanahan adalah selama dan sepanjang bukan merupakan akta pertanahan yang selama ini telah menjadi kewenangan PPAT. ${ }^{19}$ Penulis sependapat mengenai pendapat Habib Adjie mengenai:

${ }^{19}$ Habib Adjie, 2009, Hukum Notaris Indonesia, Tafsir Tematik terhadap UU No.30 tahun 2004 Tentang Jabatan Notaris, Refika Aditama, Bandung, hlm.82. 
Kewenangan Notaris dalam membuat akta pertanahan adalah selama dan sepanjang bukan merupakan akta pertanahan yang selama ini telah menjadi kewenangan PPAT.

Menurut Dr. H.Husni Thamrin, SH., MM., MH, Pasal 15 ayat 2 huruf $f$ UUJNP dengan tegas menyatakan bahwa Notaris berwenang membuat akta yang berkaitan dengan pertanahan. Dalam penjelasan pasal tersebut dikatakan "cukup jelas", padahal ketentuan tersebut sebenarnya memerlukan penjelasan berkaitan dengan masih adanya pejabat lain yang oleh peraturan perundangundangan juga diberi kewenangan untuk membuat akta di bidang pertanahan, yaitu PPAT. Ketiada penjelasan tersebut menimbulkan problematika di lapangan, karena hingga saat ini PPAT masih menjalankan tugas dan wewenangnya membuat akta pertanahan. Sementara Notaris meski oleh Pasal 15 ayat (2) huruf f UUJN telah diberi kewenangan untuk membuat akta pertanahan ternyata belum dapat menjalankan kewenangannya. ${ }^{20}$

Penulis sependapat dengan pendapat Husni Thamrin mengenai : Notaris meski oleh Pasal 15 ayat (2) huruf $f$ UUJN telah diberi kewenangan untuk membuat akta pertanahan ternyata belum dapat menjalankan kewenangannya. Belum dapat menjalankan kewenangannya dalam arti Akta Notaris tidak dapat dijadikan dasar untuk mendaftar ke Kantor Pertanahan Kota/Kabupaten.

\subsection{Ketentuan Yang Bersifat Antisifatif}

Ketentuan Pasal 15 ayat (2) huruf $f$ UUJNP bersifat antisifatif artinya ketentuan tersebut mengantisipasi jika peraturan

\footnotetext{
${ }^{20}$ Husni Thamrin, 2011, Pembuatan Akta Pertanahan Oleh Notaris, LaksBang PRESSindo, Yogyakarta, hlm.101
}

lainnya dikemudian hari mengatur tentang Notaris berwenang membuat akta pemindahan hak atas tanah dan Hak Milik Atas Satuan Rumah Susun dan pembebanan Hak Tanggungan. Peraturan Perundang-undangan maupun keputusan hakim yang bersifat mengantisipasi baik merujuk pada adanya rancangan undang-undang tertentu, atau merujuk pada kehendak pembentuk undang-undang yang berkehendak mengadakan perubahan peraturan perundangundangan lainnya. ${ }^{21}$ Kewenangan tersebut diantisipasi mengingat terdapat perbedaan bentuk antara Akta Notaris dengan bentukbentuk akta pemindahan hak atas tanah dan Hak Milik Atas Satuan Rumah Susun dan pembebanan Hak Tanggungan yang selama ini merupakan kewenangan PPAT.

Bilamana dikemudian hari pemerintah meninjau kembali Peraturan Pemerintah yang mengatur tentang PPAT dan selanjutnya mengatur bahwa setiap Notaris tidak memerlukan lagi pengangkatan khusus untuk menjadi PPAT, artinya setiap Notaris sekaligus merupakan PPAT, maka kewenangan Notaris untuk membuat akta-akta PPAT adalah berdasarkan ketentuan pasal 15 ayat (2) huruf f UUJNP. Walaupun sesuai akta itu merupakan akta otentik, namun kewenangan menurut Pasal 15 ayat (1) dengan kewenangan Pasal 15 ayat (2) huruf f perlu dibedakan. Perbedaan tersebut diperlukan karena bentuk aktanya. Bentuk akta Notaris bila kewenangannya berdasarkan ketentuan pasal 15 ayat (1) UUJN maka bentuknya harus sesuai dengan Pasal 38

${ }^{21}$ J.A.Pontier diterjemahkan oleh B.Arief Sidharta, Penemuan Hukum (rechtsvinding), cet.3,2001, Laboratorium Hukum Fakultas Hukum Universitas Katolik Parahyangan, Bandung, hlm.31. 
UUJN. Sedangkan, akta-akta PPAT terdapat beberapa perbedaan bentuk dengan akta Notaris. Bentuk akta ini sangat penting dalam hal menentukan autentik atau tidaknya suatu akta. Suatu akta otentik bilamana akta tersebut dibuat oleh pejabat umum, dibuat dalam bentuk yang ditentukan oleh undang-undang. ${ }^{22}$

Berdasarkan

dengan pembahasan di atas, menurut penulis makna pasal 15 ayat (2) huruf $f$ adalah Notaris berwenang membuat akta yang berkaitan dengan pertanahan. Kewenangan itu merupakan kewenangan khusus karena mengenai perbuatan hukum tertentu. Kewenangan Notaris dalam membuat akta pertanahan adalah selama dan sepanjang bukan merupakan akta pertanahan yang selama ini telah menjadi kewenangan PPAT dengan kata lain Notaris tidak berwenang untuk membuat akta-akta pemindahan hak atas tanah, pemindahan hak milik atas rumah susun, dan pembebanan hak atas tanah.

\section{KESIMPULAN DAN SARAN}

\subsection{Kesimpulan}

Dari pembahasan yang telah diuraikan di atas, maka dapat diambil suatu simpulan, sebagai berikut :

1. Pembatasan kewenangan Notaris terhadap kewenangan PPAT dalam proses Pemberian Hak Guna Bangunan Atas Tanah Hak Milik yaitu Notaris hanya berwenang sebatas membuat Akta Perjanjian Pendahuluan Pemberian Hak Guna Bangunan Atas Tanah Hak Milik dan Akta Kuasa. Lahirnya Akta Perjanjian Pendahuluan dan Akta Kuasa ini disebabkan oleh tidak adanya kepastian serta

${ }^{22}$ Pasal 1868 KUHPerdata. perlindungan hukum saat adanya jeda waktu yang cukup lama yaitu antara ketika uang imbalan sudah lunas dengan belum terpenuhinya syarat pembuatan akta PPAT untuk pendaftaran ke Kantor Pertanahan Kabupaten/Kota. Maka dari itu Akta Notaris ini merupakan akta awal sebagai jembatan untuk selanjutnya dibuatkan akta PPAT yang nantinya dapat digunakan sebagai dasar untuk mendaftar ke Kantor Pertanahan Kota/Kabupaten setempat. Maka dari itu fungsi Akta Notaris ini adalah dapat memberikan kepastian berupa alat bukti yang sempurna serta memberikan perlindungan hukum kepada para pihak, guna mencegah timbulnya sengketa terhadap perbuatan hukum yang dilakukannya.

2. Makna pasal 15 ayat (2) huruf f yang menentukan kewenangan Notaris dalam membuat Akta berkaitan dengan pertanahan adalah selama dan sepanjang bukan merupakan akta pertanahan yang selama ini telah menjadi kewenangan PPAT, dengan kata lain Notaris tidak berwenang untuk membuat akta-akta pemindahan hak atas tanah, pemindahan hak milik atas rumah susun, dan pembebanan hak atas tanah.

\subsection{Saran -Saran}

Dari hasil simpulan yang diuraikan di atas, dapat diberikan saran sebagai berikut :

1. Kepada Pemerintah, perlu dilakukan revisi terhadap UUJNP mengenai Pasal 15 ayat (2) huruf $\mathrm{f}$ yaitu mengenai akta-akta apa saja yang boleh dibuat oleh Notaris dalam hal kewenangan membuat akta di bidang pertanahan sehingga Pasal 15 ayat (2) huruf $\mathrm{f}$ UUJNP yang menentukan : "membuat Akta yang berkaitan dengan pertanahan" dirubah menjadi 
"membuat Akta yang berkaitan dengan pertanahan yaitu;
a. Akta Pendahuluan Jual Beli
b. Akta Pendahuluan Tukar menukar;
c. Akta Pendahuluan Hibah;
d. Akta Pendahuluan Pemasukan Ke Dalam Perusahaan (inbreng);
e. Akta Pendahuluan Pembagian Hak Bersama;
f. Akta Pendahuluan Pemberian Hak Guna Bangunan/Hak Pakai Atas Tanah Hak Milik;
g. Surat kuasa membebankan hak tanggungan
Dengan kejelasan pasal ini diharapkan tidak menimbulkan multi tafsir dan tidak menimbulkan konflik dalam pelaksanannya.

2. Kepada Notaris yang tergabung dalam organisasi INI (Ikatan Notaris Indonesia) dan PPAT yang tergabung dalam organisasi IPPAT (Ikatan Pejabat Pembuat Akta Tanah) seIndonesia khususnya Provinsi Bali hendaknya segera mengadakan pertemuan untuk membahas mengenai pemaknaan ketentuan Pasal 15 ayat (2) huruf $f$ UUJNP. Tujuannya adalah agar memiliki kesepakatan/ persamaan persepsi untuk tidak saling mengambil alih kewenangan dalam hal pembuatan akta berkaitan dengan pertanahan sehingga akta-akta yang dibuat dapat memberikan kepastian serta perlindungan hukum serta tidak menimbulkan permasalahan hukum dikemudian hari.

\section{DAFTAR PUSTAKA}

\section{Buku}

Adjie, Habib, 2009, Hukum Notaris Indonesia, Tafsir Tematik terhadap UU No.30 tahun 2004 Tentang Jabatan Notaris, Refika Aditama, Bandung.

Ali, Zainuddin, 2000, Ilmu Hukum dalam Masyarakat Indonesia, Yayasan Masyarakat Indonesia, Palu.

Attamimi, Hamid A., 1990, Peranan Keputusan Presiden republik Indonesia dalam Penyelenggaraan Pemerintah Negara; Suatu studi Analisis Mengenai Keputusan Presiden yang Berfungsi Pengaturan dalam Kurun Waktu Pelita I Pelita IV. Disertasi Ilmu Hukum Fakultas Pascasarjana Universitas Indonesia, Jakarta. 